\title{
Lithospheric versus asthenospheric source of the SW Amazonian craton A-types granites: the role of the Paleo- and Mesoproterozoic accretionary belts for their coeval continental suites
}

\author{
1 Faculdade de Geologia - Universidade do Estado do Rio de Janeiro. Rua São Francisco Xavier 524, 20559-900 Rio de Janeiro (RJ). Brazil. \\ E-mails: geraldes@uerj.br and heilbron@uerj.br \\ 2 Instituto de Geociências, Universidade de São Paulo - Rua do Lago 562, Cidade Universitária. 05508-900 São Paulo (SP) Brazil. \\ E-mail: wteixeir@usp.br
}

\begin{abstract}
The tectonic setting and source of the Paleo- and Mesoproterozoic magmatic suites in the SW Amazonian craton revealed by integrated isotopic and geochemical data allow correlation between the accretionary mobile belts and the contemporary continental magmatism (e.g. rapakivi complexes) within the foreland. The continental magmatism may represent the synorogenic response to high heat flow in the asthenosphere resulting from oceanic crust subduction, which led to the development of the successive Proterozoic magmatic arcs.
\end{abstract}

\section{Introduction}

The origin of Proterozoic rapakivi granites is controversial. Most models for this peculiar continental magmatism envision heat or magma transfer from the asthenosphere to the base of the lithosphere leading to partial melting of the lower crust.

Rämö and Haapala, (1995 and references therein) based on occurrence of rapakivi rocks along Gulf of Finland proposed that their origin was caused by thermal doming or hot spot activity beneath Baltica. Corroborating this model, Hoffman (1991) postulated that such midi-Proterozoic granites were generated by the action of a major mantle upwelling beneath the stationary Rodinia supercontinent.

Alternatively, lithosphere extension and thinning have been linked to the generation, ascent and emplacement of rapakivi magmas (Collins et al., 1982; Anderson et al., 1999; Windley, 1991; Eby, 1992). As suggested by Windley (1991), the early Proterozoic Ketilidian rapakivi granites of south Greenland are post-orogenic rocks generated by crustal melting deep within a thrust-thickened crust that had begun to undergo extensional collapse. In this case, the granites were formed during the late stages of the Ketilidian orogeny, synchronously with a period of extensional tectonics and low-pressure granulite facies metamorphism (Dempster et al., 1991). According to Collins et al. (1982), all granitic rocks with A-type affinities are intruded late in the magmatic cycle, generated by lower crust partial melting. These granites are commonly associated with extensional regimes in continental blocks, but also occur in areas that do not appear to be related to orogeny tectonic setting. This author argued against production of the A-type melts by fractional crystallization of I-type melts for two reasons: firstly, the A-type melts are initially dry or almost anhydrous, as evidenced by precipitation of biotite and amphibole only as interstitial crystals; consequently, any further fractionation from a felsic I-type melt would lead to an anhydrous melt. Secondly: the low Rb content and fairly high $\mathrm{Sr}$ content are inconsistent with their production by extensive fractionation involving feldspars. A chemical argument against the post-orogenic origin model for anorogenic suites was also proposed by Creaser et al. (1991) and Eby (1992): if the A-type granitoids were highly fractionated I-types, then the observed enrichment in trace elements would be a function of the degree of fractional crystallization. In contrast, A-type granites exhibit chemical analyses characterized by high $\mathrm{SiO}_{2}, \mathrm{Na}+\mathrm{K}_{2} \mathrm{O}, \mathrm{Fe} / \mathrm{Mg}, \mathrm{F}, \mathrm{Zr}, \mathrm{Nb}, \mathrm{Ga}, \mathrm{Sn}, \mathrm{Y}$ and REE (except $\mathrm{Eu}$ ) contents and low $\mathrm{Ca}$ and $\mathrm{Ba}$.

Other interesting example on intra-plate magmatism is reported from Australia, where the major granitic intrusions (covering 5000 $\mathrm{km}^{2}$ ) in the Monte Isa inlier are rocks with uniform A-type geochemical pattern, dated between $1870 \mathrm{Ma}$ and $1840 \mathrm{Ma}$ (Wyborn et al., 1988). Their emplacement in the upper crust is related to a tectonothermal event that produced the heat required to cause large scale melting for the generation of the A-type granites.

High precision $\mathrm{U}-\mathrm{Pb}$ data from the Gothian orogen of the southwest Sweden (Åhäll et al., 2000) indicated that westward growth of Baltica Shield occurred in a juvenile crustal accretionary belt formed on or amalgamated to the evolving continental margin, and the stepwise growth was approximately synchronous with inboard, episodic rapakivi magmatism within the craton.

This paper addresses the tectonic setting and sources of the Paleo- and Mesoproterozoic magmatic suites in the SW Amazonian craton, Mato Grosso State, Brazil. The improved chronological resolution obtained using $\mathrm{U}-\mathrm{Pb}$ and $\mathrm{Sm}-\mathrm{Nd}$ methods, added to integrated geochemical data, allows a correlation between the crustal growth of the SW Amazonian craton margin and distal coeval rapakivi magmatism within the foreland. A synorogenic model is proposed for the origin of the rapakivi complexes where the high heat flow in the asthenosphere resulted from the oceanic crust subduction that led to the development of successive accretionary arcs to the evolving continent.

\section{The SW Amazonian Craton configuration}

During the last five years systematic high resolution isotopic mapping using $\mathrm{U}-\mathrm{Pb}$ and $\mathrm{Sm}-\mathrm{Nd}$ methods in the SW Amazonian craton has led to better understanding about the framework of the Protero- 
zoic terranes. The craton has been divided (Figure 1) into two major domains (Teixeira et al., 1989; Tassinari et al., 2000): the Archean nuclei in which is included the Central Amazonian Province; and the Proterozoic Provinces, represented by the Maroni-Itacaiúnas (ca. 2.2 $\mathrm{Ga})$, the Ventuari-Tapajós (1.95-1.80 Ga), the Rio Negro-Juruena 1.79-1.52 Ga), the Rondonian-San Ignácio (1.51-1.34 Ga), and the youngest Sunsás-Aguapeí (1.24-1.00 Ga).

Each of these provinces has been divided into orogenic belts. In this way, the Rio Negro/Juruena Province is represented by the 1.79$1.74 \mathrm{Ga}$ Alto Jauru and the 1.58-1.52 Ga Cachoeirinha magmatic arcs (Van Schmus et al., 1999; Geraldes et al., 2001, respectively). The Rondonian/San Ignácio Province is marked by important events involving magmatic arc settings and continental collision processes between $1.51 \mathrm{Ga}$ and $1.34 \mathrm{Ga}$. These comprise the 1.51-1.48 Ga Rio Alegre, the 1.45-1.42 Ga Santa Helena and the 1.42-1.32 Ga San Ignácio arcs (Matos et al., 2001; Geraldes et al., 2000; Tassinari et al., 2001, respectively). Finally, the youngest Sunsás/Aguapeí Province comprises sequences deposited during basin tectonic (1.1 Ga Nova Brasilândia and 1.0 Ga Aguapeí; Rizzotto et al., 1999; Geraldes et al., 1997, respectively) and magmatic products (1.0 Sunsás; Litherland et al., 1986;).

We summarize below the characteristics of the Proterozoic evolution and major magmatic suites in SW Amazonian craton to support the contemporaneity of the juvenile accretions and the inboard magmatism.

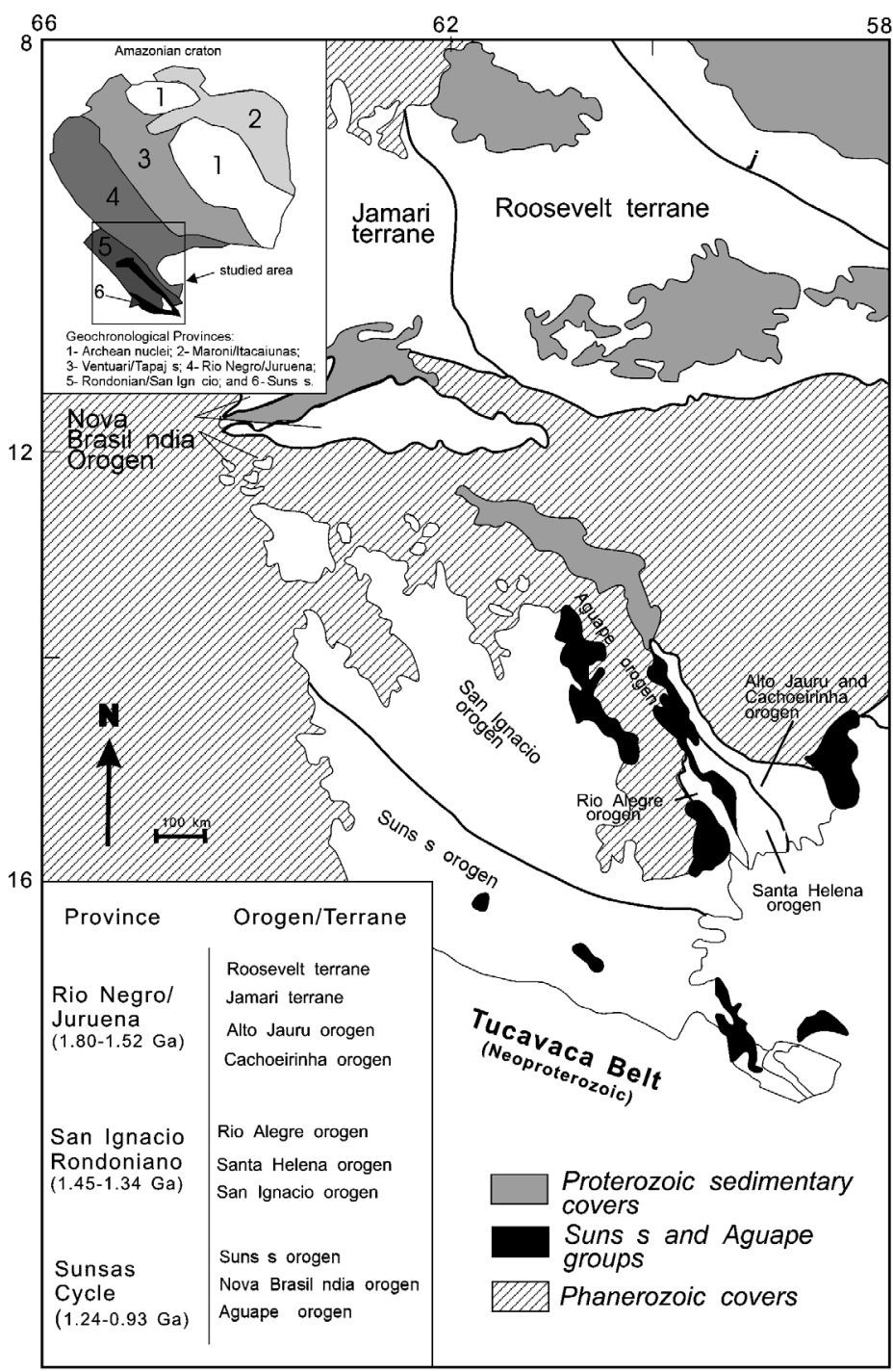

Figure 1 The accretionary events of SW Amazonian craton: each Province has been divided into orogenic events.

\subsection{9-1.74 Ga period: The Alto Jauru orogen and the Aripuanã bimodal suite}

The Proterozoic basement in SW Mato Grosso consists of igneous and metamorphic rocks interpreted as the southeastern extension of the Rio Negro/Juruena Province (Tassinari and Macambira, 1999). Precambrian basement in this region includes volcano-sedimentary belts, felsic orthogneisses and intrusive granitoids. Van Schmus et al. (1999) reported U-Pb zircon dates on volcanoclastic rocks (metatuffs) yielding $1.767 \pm 24 \mathrm{Ma}$ and $\mathrm{Sm}-\mathrm{Nd} \mathrm{T}_{\mathrm{DM}}$ model ages of $1.87 \mathrm{Ga}\left(\varepsilon_{\mathrm{Nd}(\mathrm{t})}=+2.4\right)$ indicate that volcanism was generated mostly from mantle-derived magma. This assumption is similarly supported by U-Pb zircon ages of $1747 \pm 13 \mathrm{Ma}$ and $1746 \pm 20 \mathrm{Ma}\left(\mathrm{T}_{\mathrm{DM}}=1.93\right.$ $\mathrm{Ga}$ and $1.77 \mathrm{Ga}$ and $\varepsilon_{\mathrm{Nd}(\mathrm{t})}$ values of 2.2 and 2.4 , respectively) of ortogneissic rocks (Geraldes, 2000). In addition, Pinho (1996) reported U-Pb SHRIMP results for volcanic rocks of Alto Jauru arc which yielded two age groups: the older one of $1769 \pm 29 \mathrm{Ma}$ and the youngest of $1724 \pm 30 \mathrm{Ma}$. The Roosevelt and Jamari terranes (both yielding $\mathrm{U}-\mathrm{Pb}$ ages about $1.75 \mathrm{Ga}$ ) are probably related to the Rio Negro Juruena geochronological province (Scandolara et al., 1999)

Geochemical and petrological studies on plutonic rocks indicate calc-alkaline affinity, which may be indicative of an arc related environment. Pinho et al. (1997) identified chemical results of granitoids with TTG affinity, whilst Geraldes (2000) found calc-alkaline trend. The settings of mafic and ultramafic rocks ascribed to the Alto Jauru Greenstone belt (Monteiro et al., 1986) have been interpreted by Pinho et al. (1997), who proposed an arc-related setting for the basic to intermediate rocks, and an ocean-floor setting for the ultramafic rocks.

The anorogenic magmatism coeval with the Alto Jauru orogen is represented by the Aripuan? bimodal volcanic-plutonic sequence intruded into the Ventuari/Tapajós foreland province. The studied area (Neder et al., 2002) is located in the NE corner of Figure 1, close to the Ventuari/Tapajós and Rio Negro Juruena provinces boundary. The region is dominated by granitoid rocks intruded into a sequence of acid volcanic rocks with subordinate intercalated basalts. U-Pb (SHRIMP) data yielded crystallization ages between $1762 \mathrm{Ma}$ and $1755 \mathrm{Ma}$ and chemical, isotopic and geological evidence indicate that this ensialic magmatic event may represent the tectonic stabilization process of the Ventuari-Tapajós Province.

\subsection{8-1.52 events: The Cachoeirinha orogen and the Serra da Providência Suite}

The plutonic activity in Cachoeirinha orogen comprises several tonalite to granite plutons intruded into the Alto Jauru orogen rocks (Geraldes et al., 2001). These rocks yielded U-Pb ages ranging from $1587 \pm 4$ Ma to $1522 \pm 12 \mathrm{Ma}$ with $\mathrm{T}_{\mathrm{DM}}$ from $2.05 \mathrm{Ga}$ to $1.75 \mathrm{Ga}$ and $\varepsilon_{\mathrm{Nd}}$ values from -0.8 to +1.0 . These data indicate that their magmas were probably mantle-derived but with important contribution from the Alto Jauru basement. Geochemical data are most consistent with a calc-alkaline magmatic suite, and the Cachoeirinha orogenic rocks probably represent continental margin magmatic arc activity.

The rapakivi rocks in Rondônia State reported at this time (1.58-1.52 Ga) are represented by the Serra da Providência Intrusive Suite. This unit occurs as a large $(140 \times 40 \mathrm{~km})$ elongated ovalshaped batholith (Bettencourt et al., 1999) consisting of gabbrocharnockite-mangerite-granite as well as satellite stocks described in the southeastern part of the Rondônia Tin Province. The U-Pb age reported by Bettencourt et al. (1999) range from $1606 \pm 24$ Ma to $1566 \pm 5 \mathrm{Ma}$. These results are in agreement with the zircon U-Pb SHRIMP age of $1588 \pm 16 \mathrm{Ma}$ obtained in a granitic rock (A-type) in the same region reported by Tassinari and Macambira (1999). 


\subsection{5-1.40 Ga events: The Santa Helena orogen and the Rio Branco and the Santo Antonio Intrusive Suites.}

The Santa Helena batholith is a large $(30 \times 75 \mathrm{~km})$ NW-elongated body comprised granitoids whose U-Pb zircon ages cluster within a relatively narrow range of $1444 \pm 21$ to $1424 \pm 11 \mathrm{Ga}$, indicating that the diverse phases of the batholith were emplaced as part of a major magmatic episode (Geraldes et al., 2001). The Sm-Nd $\mathrm{T}_{\mathrm{DM}}$ results range from $1.48 \mathrm{Ga}$ to $1.63 \mathrm{Ga}$, with $\varepsilon_{\mathrm{Nd}(\mathrm{t})}$ values ranging from +2.6 to +4.0 . The strongly positive $\varepsilon_{\mathrm{Nd}(\mathrm{t})}$ values added to chemical results (Bell et al., 1999) indicate that the magmas for the Santa Helena rocks were derived largely from juvenile or nearly juvenile source.

The contemporary inboard magmatic activities related to development of the Santa Helena orogen are characterized in Mato Grosso State by the Rio Branco Intrusive Suite (Geraldes et al., 1999). This unit has been considered as part of a bimodal igneous suite, comprising coeval mafic and felsic rocks which is confined within the volcanic-plutonic rocks of the 1.79-1.52 Rio Negro Juruena Province. U-Pb isotopic analyses of zircons from the granites yielded an upper intercept age of $1423 \pm 2$ Ma while those from an associated gabbro yielded an age of $1471 \pm 31 \mathrm{Ma}$. Sm-Nd $\mathrm{T}_{\mathrm{DM}}$ ages vary from 1.73 to $1.80 \mathrm{Ga}$ for the mafic rocks $\left(\varepsilon_{\mathrm{Nd}(\mathrm{t})}\right.$ values from +1.24 to +1.91$)$ and from $1.81 \mathrm{Ga}$ to $1.89 \mathrm{Ga}$ for felsic rocks $\left(\varepsilon_{\mathrm{Nd}(\mathrm{t})}\right.$ values from +0.16 to -0.96 ), which suggest that these rocks had an older continental lithosphere component in their magma. Similar model ages $(1.93-1.77 \mathrm{Ga})$ were recorded in the surrounding Alto Jauru basement.

The anorogenic magmatic units ascribed to the Santa Helena orogen in northern Rondonia, particularly in the Rondonia Tin Province (Bettencourt et al., 1999), comprise distinctly bimodal intraplate rapakivi suites, which intruded the ca. 1.75-1.53 Ga Rio Negro/Juruena crust. This magmatism is represented by the Santo Antonio and Teotônio Intrusive Suites (U-Pb ages of $1406 \mathrm{Ma}$ and $1387 \mathrm{Ma}$, respectively).

\subsection{1-1.42 Ga events: The San Ignácio orogen and the Teotônio and Alto Candeias Intrusive Suites}

The San Ignácio orogen comprises a significant syn- to post-tectonic granitoid magmatism (Litherland et al., 1986) represented by a calcalkaline complex (Rb/Sr ages about 1.32 to $1.28 \mathrm{Ga})$ and by the El Tigre alkaline Complex (1286 $\pm 46 \mathrm{Ma}$ ). Darbyshire (2000) reported $\mathrm{Sm}-\mathrm{Nd}$ results from the same samples studied by Litherland et al. (1986), with $\mathrm{T}_{\mathrm{DM}}$ between 2.09 to 1.51 and ( $\mathrm{Nd}$ values from -0.9 to +3.9. Geraldes et al. (2002) suggested a possible extension of this unit in Brazil, for which SHRIMP and conventional U-Pb dating yielded ages from 1.42 to $1.36 \mathrm{Ga}$. These results obtained in tonalites and granodiorites were interpreted as magmatic event ascribed to the San Ignácio orogen.

The San Ignácio arc accretion in Bolivia and Brazil was followed in northern Rondônia by a prolonged period of voluminous anorogenic rapakivi plutonism (Bettencourt et al., 1999) and metamorphism (Tassinari et al., 1999) probably the thermal effects of rapakivi complex intrusions. Two distinct intraplate rapakivi age groups which intruded the 1.75-1.53 Ga Rio Negro/Juruena crust are represented by the Alto Candeias (1338-1346 Ma) and São Lourenço-Caripunas (1314-1309 Ma) suites. Despite the interpretation considering the age of $1.34 \mathrm{Ga}$ as the time of regional metamorphism (Tassinari et al., 1999) assigned to the Rondonian/San Ignacio Orogeny, we can also consider that the U-Pb age of 1.34 Ga could represent the Alto Candeias thermal effects leading to granulitization of the older Rio Negro-Juruena gneisses. Recent U-Pb and Sm-Nd data of gneissic rocks of the northern Rondonia, reported by Payolla et. al. (2002), suggest a high-grade metamorphism at 1.33-1.31 Ga, which corroborate with the Tassinari et al, (1999) results and suggests a thermal event linked to anorogenic magmatism.

\section{1-0.99 Ga events: The Sunsás orogen and the Santa Clara Intrusive Suite and the Younger Granites}

The Sunsás cycle (Litherland et al., 1986) began with an important continental distension event, which involved alkaline plutonism and deposition of the Sunsás Group rocks. The geochronological data, based mainly on $\mathrm{Rb} / \mathrm{Sr}$ and $\mathrm{K} / \mathrm{Ar}$ ages, suggested that metamorphism, deformation and plutonism of this belt extended from 1280 Ma to $950 \mathrm{Ma}$. The Sunsás orogen (ca. $1000 \mathrm{Ma}$ ) which occurs in the southern part of the San Ignácio orogenic rocks is represented by reactivated basement, sin- and post-tectonic granitoids, and sparse outcrops of metasedimentary rocks. The San Diablo granitoids, described in the southernmost part of the Sunsás Orogen, are interpreted (Saes and Fragoso-Cesar, 1996) as juvenile magmatic products formed during the S-SW dipping subduction zone responsible for Sunsás magmatic arc.

The effects of the Sunsás orogen in the northern Rondônia region occurred between $1.07 \mathrm{Ga}$ and $0.97 \mathrm{Ga}$ (Bettencourt et al., 1999). The magmatism in Rondônia is composed of rapakivi granites and associated mafic rocks, including the Santa Clara Intrusive suite $(1.07 \mathrm{Ga})$ and Younger Granites of Rondônia (1.0-0.97 Ga). The Santa Clara Intrusive suite encompasses the granites from the following massifs: Santa Clara, Oriente Velho, Oriente Novo, and Manteiga. The older rock association is composed of porphyritic quartz-monzonite, monzonite and syenogranite with subordinated amounts of quartz-monzonite and less pyterlite. Biotite and minor hornblend are the main mafic minerals and zircon, apatite, ilmenite, magnetite, allanite, fluorite and sphene are essential minerals. A younger association includes syenite, trachyte and peraluminous and peralkaline granites

The Younger Granites of Rondônia are subdivided by Leite Jr, (1996) and Bettencourt et al.,(1999) into two distinct suites. The first one is composed of metaluminous to marginally peraluminous subsolvus and subalkaline features with minor associated quartz-syenite, quartz-monzonite, monzonite and the second, restricted in area, shows an hypersolvus character and as well alkaline affinity. The field relationships suggest that the alkaline rocks are younger than the subalkaline types.

\section{Discussion and conclusion}

The western part of the Amazonian craton is a multi-orogenic region formed between 1.8 and $1.0 \mathrm{Ga}$ (Figure 2) where successive magmatism, metamorphism, and deformation took place. Therefore, juvenile accretionary events progressively amalgamated to the older continental margin during the Paleo- and Mesoproterozoic times gives the framework of the evolution of the SW Amazonian craton, like Baltica and Laurentia shields.

The definition of distinct accretionary stages on the older crust and their temporal correlation of these stages with the rapakivi episodes (Figure 3) suggest that the latter were probably related to processes occurring at the evolving continental margin. Therefore, the temporal link between orogenic belts and the peculiar continental magmatism in SW Amazonian craton may be explained by reorganization of intracratonic lithosphere stresses when each episode of subduction stepped westward (actual). We concur with existing petrogenetic models for the origin of the rapakivi granites, which their generation in lower lithosphere sources may be explained by decompression melting, with ascent probably guided by features of the pre- 

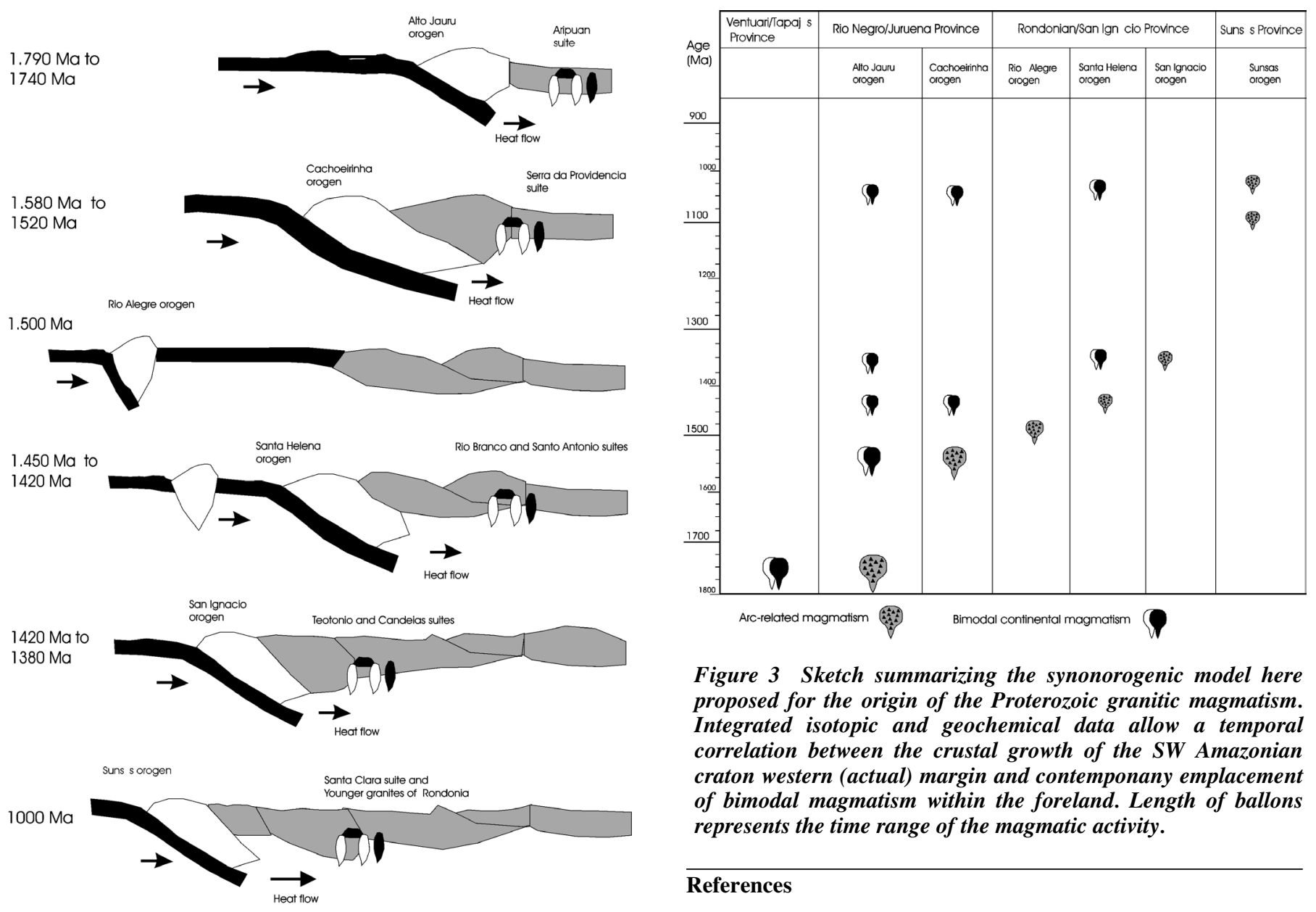

Figure 2 Hypothetical sketch for the evolution of SW Amazonian craton from $1.8 \mathrm{Ga}$ to $1.0 \mathrm{Ga}$. Ages are refered to $\mathrm{U}-\mathrm{Pb}$ (conventional and SHRIMP) data. The juvenile arc-related magmatisms have their coeval bimodal magmatism within the continent.

cursor accretionary event. In addition, the genetic link of accretionary events and rapakivi magmatism hypotheses may take into account (i) an overthickened lithosphere which attempted to regain isostatic equilibrium, resulting in extensional collapse, and (ii) the mantle conditions beneath the large and immature crustal terrane of the arc-accretionary SW sector of the Amazonian craton had quite constant conditions from 1.8 to $1.0 \mathrm{Ga}$. This means that the new accretionary setting always found a sialic crust formed recently, what may have important consequences for the high heat flow beneath it.

Up to now, the Rio Alegre accretionary event does not have respective inboard magmatism reported. The 1.51-1.50 Ga Rio Alegre orogen is the only juvenile magmatic event with lack of coeval rapakivi complexes which may be explained probably due to the origin of this magmatism. It had taken place away (as an exotic terrane) from the continental margin of the Amazonian craton at that time, as speculated in Figure 2.

The hypothesis here presented also has consequences for the paleogeographic reconstruction of a Mesoproterozoic (1.6-1.5 Ga) supercontinent. If the correlation between accretionary belts and continental magmatism is correct, and if there are temporal correlations between accretionary belts and rapakivi granites in Baltica, Laurentia and Amazonia, then the paleogeographic configurations of these continental masses should show the juxtaposition of a continuously evolving margin with contiguous landmasses in which intracontinental magmatism was taking place.

Figure 3 Sketch summarizing the synonorogenic model here proposed for the origin of the Proterozoic granitic magmatism. Integrated isotopic and geochemical data allow a temporal correlation between the crustal growth of the $S W$ Amazonian craton western (actual) margin and contemponany emplacement of bimodal magmatism within the foreland. Length of ballons represents the time range of the magmatic activity.

\section{References}

Åhäll, K-I, Connelly, J.N., and Brewer, T.S., 2000. Episodic rapakivi magmatism due to distal orogenesis?: correlation of 1.69-1.50 Ga orogenic and inboard, "anorogenic" events in the Baltic Shield. Geology, 28:823826.

Anderson, J. Söderlung, U., Cornell, D., Johansson, L., Möller, C. 1999. Sveconorwegian (Grenvillian) deformation, metamorphism and leucosome formation is SW Sweden, SW Baltic Shield: constraints from a Mesoproterozoic granite intrusion. Precambrian Research, 98:151-171.

Bell, S., Condie, K. and Geraldes, M.C., 1999. Origin of arc-related granitoids from the SW Amazon craton: Juvenile crustal additions at 15501450 Ma. The Geological Society of America 1999 Annual Meeting. Denver-CO. Abstract with Programs, 205.

Bettencourt, J.S., Tosdal, R.M., Leite JR., W.B., and Payolla, B.L., 1999. Mesoproterozoic rapakivi granites of the Rondônia Tin Province, southwestern border of the Amazonian craton, Brazil - I. Reconnaissance U-Pb geochronology and regional implications. Precambrian Research 95:4167.

Creaser, R.A.; Price, R.C.; and Wormald, R.J. 1991 A-type granites revisited:assessment of a residual-source model. Geology 19:163-166.

Collins, W.J. Beans, S.D., White, A.J.R. and Chappell, B.W. 1982 nature and origin of A-type granites with particular references to southeastern Australia. Contribuitions to Mineralogy and Petrology 80:189-200.

Dempster, T.J., Hutton, D.H.W., Harrison, T.N., Brown, P.E. and Jenkin, G.R.T. 1991 Textural evolution of the rapakivi granites, south Greenland- $\mathrm{Sr}, \mathrm{O}$ and $\mathrm{H}$ isotopic investigations. Contribuitions to Mineralogy and Petrology, 107:459-471.

Darbyshire, D.P.F. 2000 The Precambrian of Eastern Bolivia - a Sm-Nd isotope study. In: 31 International Geologic Congress, Rio de Janeiro, Brazil. Abstract Volume (CD-Room).

Eby, G.N. 1992 The A-type granitoids: a review of their occurence and chemical characteristics and speculations on their petrogenesis. Lithos 26:115-134.

Geraldes, M.C., 2000. Geoquímica e Geocronologia dos plutons graníticos Mesoproterozóicos do SW do Estado de Mato Grosso (SW do Cráto Amaz?nico). Universidade de São Paulo, São Paulo-SP, Brazil, unpublished Doctoral dissertation, $185 \mathrm{p}$. 
Geraldes, M.C., Figueiredo, B.R., Tassinari, C.C.G., and Ebert, H.D., 1997. Middle Proterozoic vein-hosted gold deposits in the Pontes e Lacerda region, southwestern Amazonian craton, Brazil. International Geology Review 39:438-448

Geraldes, M.C., Bettencourt, J.S., Van Schmus, Teixeira, W., e Matos, J.B 1999. The Mesoproterozoic Rio Branco suite, SW Amazon Craton, Brazil: A reconnaissance isotope study on a bimodal magmatic complex. In The origin of Granites and Related Rocks. B. Barbarin (ed.). Abstracts of Forth Hutton Symposium: p. 149.

Geraldes, M.C., Teixeira, W., and Van Schmus, W.R., 2000. Isotopic and chemical evidence for three accretioary magmatic arcs $(1.79-1.42 \mathrm{Ga})$ in SW Amazon craton, Mato Grosso state, Brazil. Revista Brasileira de Geociências 30:99-101.

Geraldes, M.C., Tassinari, C.C.G., Teixeira, W., and Van Schmus, W.R., 2002. Geocronologia U-Pb convencional e SHRIMP e Sm-Nd de rochas granitóides na Serra Santa Bárbara (SW do Estado do Mato Grosso) Uma possível extensão do orógeno San Ignácio da Bolívia (?) Contribuições a Geologia da Amazônia, vol. III: 143-152

Geraldes M.C. Van Schmus, W.R., Condie, K.C.; Bell S.; Teixeira, W. Babinski, M. 2001. Proterozoic Geologic Evolution of the SW Part of the Amazonian Craton in Mato Grosso State, Brazil. Precambrian Research, 111:91-128.

Hoffman, P.F., 1991. Did the breakout of Laurentia turn Gondwanaland inside out? Science 252:1409-1412.

Litherland, M.; Annels, R.N.; Appleton, J.D.; Berrange, J.P.; B;oomfield, K.; Burton, C.C.J.; Darbyshire, D.P.F.; Fletcher, C.J.N.; Hawkins, M.P.; Klink, B.A.; Llanos, A.; Mitchel, W.I.; OConnors, E.A.; Pitfield, P.E.J.; POWER, G e werb, b.c. 1986 tHE Geology and Mineral Resources of the Bolivian Precambrian Shield. British geological Survey. Overseas Memoir 9. London, Her Majesty \%os Stationery Office. 140 p.

Matos, J.B., Schorscher, J. H. D., Geraldes, M. C. and Souza, M. Z. A. 2001 The Rio Alegre Volcanosedimentar Sequence (SW Amazonian Craton, Brazil): Chemical and Isotope $(\mathrm{U} / \mathrm{Pb}$ and $\mathrm{Sm} / \mathrm{Nd})$ constrain and tectonic implications Geology of the SW Amazonian Craton: State-of-the-Art". Extended Abstract Volume. p. 56-59.

Monteiro, H., Macedo, P.M., Silva, M.D., Moraes, A.A., and Marcheto, C.M.L., 1986. O greenstone belt do Alto Jaurú. XXXIV Congresso Brasileiro de Geologia 2, 630-646.

Neder, R.D.N., Leite, J.A. D., Figueiredo, B.R., McNaughton, N.J. 20021.76 Ga volcano-plutonism in the southwestern Amazonian craton, AripuanãMT, Brazil: Tectono-stratigraphic implications from SHRIMP U-Pb zircon data and rock geochemistry. Precambrian Research 119:171-187.

Payolla, B. L , Bettencourt, J.S. Kozuch, M., Leite, Jr, W.B., Fetter, A.H. and Van Schmus, W.R. 2002 Geological evolution of the basement rocks in the east-central part of the Rondônia Tin Province, SW Amazonian craton, Brazil: $\mathrm{U}-\mathrm{Pb}$ and $\mathrm{Sm}-\mathrm{Nd}$ isotopic constraints, Precambrian Research 119:141-169.

Pinho, F.E.C., 1996 The origin of the Cabaçal $\mathrm{Cu}-\mathrm{Au}$ deposit, Alto Jauru greenstone belt, Brazil. University of Western Ontario, London-ON, Canada, Ph.D. thesis, $211 \mathrm{p}$.

Pinho, F..E.C., Fyfe, W.S., and Pinho, M.A.S.B., 1997. Early Proterozoic evolution of the Alto Jauru greenstone belt, southern Amazonian craton, Brazil. International Geology Review 39:220-229.

Ramö, T. and Haapalla, I., 1995 One hundred years of Rapakivi granite. Menir. Petrol. 52:129-185.

Rizzotto, G.L., Chemale Jr.,F., Lima. E.F., Van Schmuss, R., \& Fetter, A., 1999. Dados isotópicos Sm-Nd e U-Pb das rochas da Sequêfncia metaplutono-vulcanossedimentar Nova Brailandia (SMNB) -RO (1999) - VI Simpósio de Geologia da Amazônia, Ext. Abstract Bull., p.490-493.

Saes, G.S.; \& Fragoso Cesar, A. R. S. 1996. Acresção de terrenos mesoproterozóicos no SW da Amazônia. In: 39 Congresso Brasileiro de Geologia Abstracts p.348

Scandolara, J.E., Rizzotto, G.J., de Amorim, J.L., Bahia, R.B.C., Quadros, M.L., \& C.R. da Silva, 1999. Geological map of Rondônia 1:1,000,000. Companhia de Pesquisa de Recursos Minerais.

Tassinari, C.C.G. \& Macambira, M.J.B, 1999. Geochronological Provinces of the Amazonian Craton. Episodes, 22(3):174-182.

Tassinari, C.G., Bettencourt, J.S., Geraldes, M.C., Macambira, M.J.B., and Lafon, J.M., 2000. The Amazon craton. In Cordani, U., Milani, E.J., Thomaz Filho, A., and Campos, D.A., eds., Tectonic evolution of South America, 31st International Geological Congress, Rio de Janeiro, Brazil, 41- 95

Teixeira, W., Tassinari, C.C.G., Cordani, U.G., and Kawashita, K., 1989. A review of the geochronology of the Amazonian craton: tectonic implications. Precambrian Research 42:213-227.

Van Schmus, W.R., Geraldes, M.C., Fetter, A.H., Ruiz, A., Matos, J., Tassinari, C.C.G., and Teixeira, W., 1999. Jauru Terrane: A late Paleoprotero- zoic orogen in SW Amazon craton, Mato Grosso State, Brazil. European Union of Geosciences Meeting (EUG-10), Journal of Conference Abstracts 4, 129-130.

Windley, B.F. 1991 Early Proterozoic collision tectonics, and rapakivi granites as intrusions in an extensional thrust-thickened crust: the Ketilidian orogen, south Greenland. Tectonophysics, 195:1-10.

Wyborn, L.A.I., Page, R.W. and McCulloch, M.T. 1988 Petrology, Geochronology and isotope geochemistry of the post-1820 Ma granites of the Mount Isa inlier: mechanisms for the generation of Proterozoic anorogenic granites. Precambrian Research, 40/41:509-541.

Mauro Cesar Geraldes is professor of Geochronology at Faculty of Geology/Rio de Janeiro State University/Brazil. He worked in the mineral industry in Amazonia region from 1998 to 1994 and got his master degree in State University of Campinas (Brazil) in economic geology. He received his $P h D$ in geochemistry and geochronology from University of São Paulo (Brazil)/University of Kansas (EUA) in 2000. He earned post-doctorates at University of São Paulo on metallogeny. His current research is focused on crustal evolution and its temporal correlations with mineral deposits.

Wilson Teixeira is a Full Professor of the Geosciences Institute of the University of São Paulo (USP), and member of the Geochronological Research Center of this institution. Director of the Estação Ciências of USP. Member of the Brazilian Academy of Sciences, and researcher $1 A$ of the Brazilian National Research Council, CNPq. Co-leader of IGCP-204 "Evolution of the Amazonian Craton (UNESCO/ IUGS 1983-1987). Main areas of interest: geochronology and crustal evolution of Archean and Proterozoic terranes and tectonics of Precambrian mafic dikes.

Monica Heilbron is professor of Geotectonic at Faculty of Geology/ Rio de Janeiro State University/ Brazil. She is also the head of the TEKTOS Research Group that works on several themes related with geological mapping, tectonics, geochronology, petrology and their applications on economic geology and environment problems. She got her $P h D$ degree at São Paulo University in 1993. Her major interest is related to the tectonic evolution of the Neoproterozoic Ribeira belt, SE Brazil, and its relationship with the amalgamation of Western Gondwana. More recently she is working with the basement reactivation during the break-up of Gondwana and the tectonic inheritance at Campos and Santos basin.
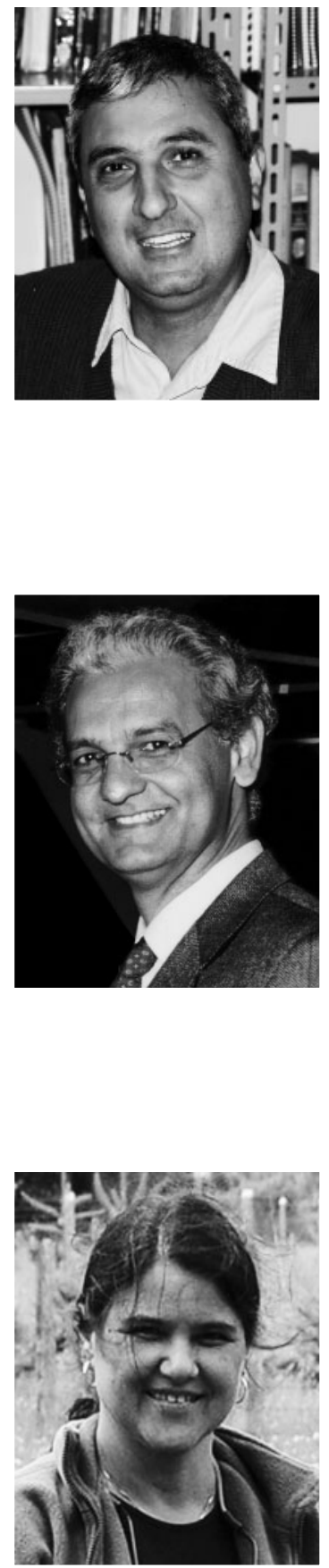